Volume 8. No. 7, July 2020

International Journal of Emerging Trends in Engineering Research

Available Online at http://www.warse.org/IJETER/static/pdf/file/ijeter142872020.pdf

https://doi.org/10.30534/ijeter/2020/142872020

\title{
LPG - CNG - Biofuel for Land Transportation Fuel in Indonesia: Overview, Opportunities, and Challenges
}

\author{
Affan Rifa' $\mathbf{i}^{1^{*}, \text { Saifudin }^{2}}$ \\ ${ }^{1}$ Dept. of Industrial Engineering, Universitas Muhammadiyah Magelang, Indonesia, affan_r@ummgl.ac.id \\ ${ }^{2}$ Dept. of Automotive Engineering, Universitas Muhammadiyah Magelang, Indonesia, saifudin@ ummgl.ac.id
}

\begin{abstract}
The rate of Indonesian oil imports has increased from 1980 to the present, despite fluctuations. The transportation sector is the largest oil consumption above the industrial and household sectors. The availability, price, and environment factors also make a reason to think about cleaner fuels. Therefore, we conducted a review of the experience of implementing alternative fuels. At present, LPG, CNG, ethanol and biodiesel are good candidates to replace conventional fuels for land transportation in Indonesia. For gas-based fuels, LPG is relatively easy to implement because it only requires a slight modification to the engine but it is not suitable for the future because it is a refinery product. CNG provides advantages over LPG. The lower carbon content and high octane number provide better environmental effects and can be applied to machines with a higher compression ratio. For biofuels, ethanol has almost all the main characteristics for cleaner SI engine fuels. Indonesia has abundant biodiversity to produce ethanol. However, large-scale production will conflict with the availability of land for food crop production. Biodiesel has been produced on a large scale in Indonesia. Palm oil, Jatropha curcas, sunflowers and all seeds containing oil can be planted on all islands in Indonesia. One feature of biodiesel is that it can be applied independently or mixed with diesel oil. With improved quality, biodiesel can be applied to diesel engines without engine modification. This makes biodiesel more feasible for diesel engines than ethanol for gasoline engines.
\end{abstract}

Key words: Alternative fuel, Land transportation, LPG, CNG, Ethanol, Biodiesel.

\section{INTRODUCTION}

Between 2013 and 2025, the Indonesian population is projected to grow at $0.7 \%$ per annum while GDP is projected to grow at $4.6 \%$ [1]. In turn, the economic growth combined with population growth will result in higher demand for energy. In 2000, Indonesian gross energy consumption was
BOE 777,925,086. This increased to $1,114,766,960 \mathrm{BOE}$ in 11 years period, or in total reached $43.3 \%$. As of 2017, the transport sector has grown to be the largest energy user, consuming 574,795 thousand $\mathrm{BOE}$, or $46.58 \%$ of the national energy consumption. Transportation energy growth is worrying because of the increasing automotive market. Although automotive manufacturers are promoting fuel-efficient cars, it has not been able to compensate for the increase in the number of vehicles.

In addition, from 2000 to 2011 oil production decreased by $4 \%$ annually due to the depletion of reserves while additional exploration and development spending was insufficient [2]. Therefore the key challenge facing Indonesia's energy sector becomes the sustainability issue. Considering that Indonesia's oil consumption has now exceeded Indonesia's domestic oil production, increased oil demand would put growing pressure on the economy as a result of increased oil imports. Therefore, Indonesia will promote and facilitate the use of renewable energy to achieve energy control, including energy management, the coordination of energy sector legislation, as well as the development of technology for high energy demand, in addition to optimizing different sectors of heavy energy use, in particular oil consumption. Therefore, comprehensive efforts and cross-sectional coordination to reduce oil use in the road transport sector will clearly make a significant contribution to overall national oil consumption.

In 2014, the Indonesian government established a National Energy Policy (KEN) through Government Regulation Number 79 of 2014. The basis for the issuance of this Government Regulation (PP) is article 11 paragraph 2 of Law Number 30 of 2007. The stipulated KEN also been approved by parliament through DPR Decree Number 01/DPR $\mathrm{RI} / \mathrm{III} / 2013-2014$. As is known, $\mathrm{KEN}$ is a guideline to provide direction for national energy management to support sustainable national development. Therefore, the future direction of energy policy is guided by the paradigm that energy resources will be used as national development capital. The establishment of KEN aims to: (a) realize energy management independence, (b) ensure the availability of energy and meet the needs of domestic energy sources, (c) optimize the management of energy resources in an integrated and sustainable manner, (d) increase the efficiency 
of energy use, (e) ensuring fair and equitable access to energy, developing technological capabilities, the energy industry and domestic energy services, (f) creating jobs and controlling the effects of climate change and maintaining environmental functions. Subsequently, the KEN was revealed to be the National Energy General Plan (RUEN). RUEN is prepared by the Government and stipulated by the National Energy Council for a period up to 2050 which contains the current national energy conditions and future expectations; national energy vision, mission, goals and objectives; and national energy management policies and strategies [3].

At present, accelerated vehicle retirement programs (AVRPs) for older vehicles with low efficiency may be an effective way to reduce fuel consumption and emissions [4]-[6]. However, the AVRPs program seems to be still difficult in Indonesia because of policies and related to the national economy. Incentive schemes for the purchase of a new fleet require cross-sectoral coordination while considering community purchasing power. Meanwhile, implementing strict standards on road vehicle emissions might stop some of the fleet and risk threatening economic growth [7], [8]. Seeing these conditions, replacing conventional fuels (gasoline and diesel) with cleaner alternative fuels is a reasonable option. Therefore, this article presents a review of alternative fuels that might be applied in Indonesia for the present and the future.

\section{METHOD}

In this study, we conducted a review of three types of fuels that could be applied for the land transportation sector in Indonesia, namely LPG, CNG, ethanol and biodiesel. LPG, $\mathrm{CNG}$, and biodiesel have been implemented for a long time with good consumer acceptance. Meanwhile, although ethanol has not been practiced commercially for the transportation sector, Indonesia has abundant local plant potential for ethanol, such as sugar cane, cassava, tubers and all biological natural resources that contain cellulose. An overview of each fuel will be presented, including a report on its implementation. Then, we will make an evaluation of the opportunities and challenges for implementation. Finally, we will make a conclusion and recommendation as a reference for policymakers and practitioners to make the right choices.

\section{RESULT AND DISCUSSION}

\subsection{Liquefied Petroleum Gas (LPG)}

LPG is the most common alternative fuel for SI engines, but overall average energy consumption in the transport sector is still small. For only a few countries, such as the Netherlands, Turkey and Poland, LPG makes a major difference to passenger vehicles. In developing countries such as India and Turkey, during 2013-2017, there was an increase in the number of LPG vehicles but tended to decline in developed countries such as South Korea and Japan because of the penetration of electric vehicles that were more environmentally friendly [9]. The high octane number (especially propane) enables it to be applied to SI engines with higher compression ratios so that its thermal efficiency is higher. LPG fuel consumption is lower than gasoline but is usually still higher than diesel fuel consumption. NOx emissions produced by LPG engines are close to gasoline engines but are lower for other emissions $(\mathrm{CO}, \mathrm{HC})$ than the use of gasoline [10]. This is one of the benefits of using LPG for LDV (Light Duty Vehicle) vehicles. At ambient pressure and temperature, LPG is stored in a liquid state at a pressure of 6-12 bar. In vehicles, LPG tanks are bigger than gas tanks for the same energy content. It is almost twice its size and weighs more than 1.5 times that of a gas tank to hold the amount of energy equivalent to gasoline.

A relief valve is installed in the tank as a safety if the LPG pressure rises above 20 bar. LPG tanks in vehicles must not be filled more than $80 \%$ to $85 \%$ of their capacity. The remaining $15 \%$ to $20 \%$ space is used for compensation space when fuel expansion occurs due to temperature and pressure increases. LPG is generally considered a safe fuel. When a leak occurs, LPG vapors tend to approach the ground surface. For this reason, in some countries it is forbidden to park LPG cars in lower basement parking facilities. LPG is easier to blend with air and more flammable than gasoline and diesel. LPG is safer because the tank is designed as a pressure vessel, so that during an accident there will be almost no fuel spills [11].

In Indonesia, the application of LPG to LDVs as public transport has begun since 1988. Nevertheless, it will not grow for the next 30 years. In the $2007 \mathrm{~s}$, the government introduced LPG as an alternative fuel for road vehicles [12]. Government incentives are initiated by providing free-of-charge converter kits for public transport in many cities such as Jakarta, Surabaya, Bogor and Palembang as a pilot project. Over the period 2007-2011, more than 5000 LPG kits were promoted for public transport. The Government provided technical guidelines on requirements for converter kits, infrastructures, workshops and technicians. Then, Pertamina as one of the state-owned enterprises are slowly building a refueling site network in many cities. Now, LPG refueling site has been available in Jakarta, Surabaya, Bandung, Bogor, Palembang, Semarang, Solo, Yogyakarta, Denpasar, and Magelang [13]. However, the infrastructure available for PG is still far behind the infrastructure for gasoline [14].

After implementation for taxis, public transportation and private vehicles, in 2016 PT Garuda Indonesia (a government-owned airline) required all crew to switch to LPG. However, promotion of the use of LPG for a broader scale is still constrained, the high cost of conversion and availability of gas stations is still a reason for refusing to switch to LPG. Various implementation studies are also carried out on a massive scale by scholars [15]-[20]. Although switching from gasoline to LPG is economically 
profitable, this conversion program is sensitive to fuel price ratios (LPG to gasoline) and daily mileage, except for public transportation, with government financing schemes [21]-[25]. Figure 1 presents a photographic view of LPG implementation in Indonesia.

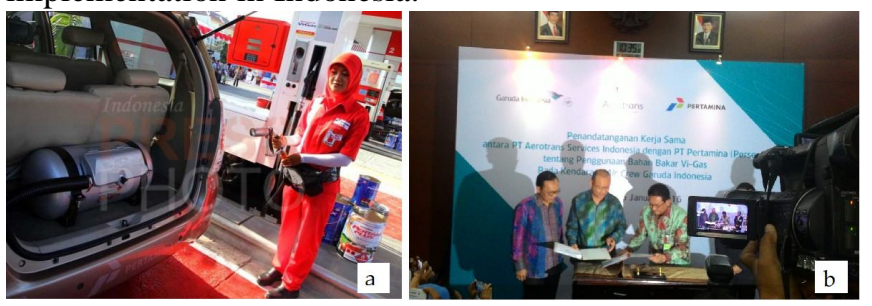

Figure 1: Some photographic views of LPG implementation for vehicles in Indonesia: (a) Activities at the gas station, captured by beritatrans.com and (b) Inauguration of Garuda Indonesia Airways

crew vehicle operation with LPG, captured by kicaunews.com

\subsection{Compressed Natural Gas (CNG)}

Compressed Natural Gas CNG, especially methane $\left(\mathrm{CH}_{4}\right)$, is the only fuel that requires almost no significant processing for automotive use. Methane occurs naturally in the earth's crust. Natural gas only requires drying and purification in the form of removal of hydrogen sulfide $\left(\mathrm{H}_{2} \mathrm{~S}\right)$. Natural gas is converted into synthesis gas ("syngas") and becomes a raw material for producing methanol and DiMetil Ether (DME) as well as for hydrogen recovery. Italy, Argentina, New Zealand, Russia and the United States have a significant natural gas vehicle (NGV) fleet, but are not yet the dominant motor vehicle fuel. Countries that already have natural gas distribution channels can promote it as a relatively easy vehicle fuel. However, for countries that do not yet have reliable infrastructure, it requires very expensive investment to build. These constraints make natural gas less an option for solving short-term problems.

Like LPG, CNG has a high octane number (120), which allows it to be applied to engines with a higher compression ratio and can increase thermal efficiency by around 10\% from gasoline use. The efficiency of NGV is generally lower than the use of gasoline (15\% to $20 \%$ ). Under ambient conditions, natural gas has a very low energy content, but in liquid form it is as good as LPG. Natural gas storage pressure (CNG) reaches 200-240 bar, so it requires equipment and infrastructure that is far more expensive than LPG.

Indonesia has potential reserves for $\mathrm{CNG}$ production. This presents an open opportunity to implement CNG for transportation [26]. Currently, CNG prices are very competitive compared to subsidized gasoline and diesel. However, this price difference has not been an adequate incentive to stimulate investment in $\mathrm{CNG}$ refueling infrastructure by the private sector and the general public has also shown an unwillingness to adopt $\mathrm{CNG}$ as a transportation fuel [27]. However, the consistent implementation of $\mathrm{CNG}$ for buses such as TransJakarta, Trans-Semarang, and Bajaj is proof that CNG is more promising than LPG (Some photographic views of CNG implementation is presented in Figure 2). Indeed, in wide-scale implementation, investment for $\mathrm{CNG}$ is more expensive than LPG to build infrastructure.

Like LPG, many studies report the benefits of CNG for the transportation sector in Indonesia compared to gasoline and diesel [27]-[30]. CNG has better environmental effects than LPG and gasoline. However, due to its properties, the volumetric efficiency of CNG is lower than that of gasoline and LPG, which makes one of the reasons for the decline in engine power output. Expensive conversion costs can be completed with a government-funded conversion program or by providing incentives for vehicle owners who want to convert their vehicles to CNG. Incentives can be in the form of fiscal incentives including vehicle ownership taxes and free supply of converter equipment [31].
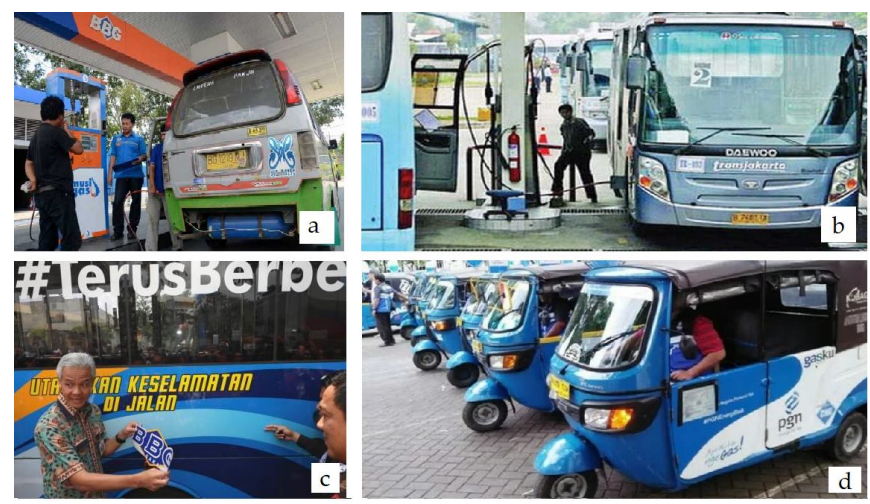

Figure 2: Some photographic views of CNG implementation in Indonesia: (a) Micro fleet, captured by republika,co.id; (b)

TransJakarta, captured by investor.id; (c) Trans-Semarang, captured by infopublik.id; and (d) Bajaj powered by CNG, captured by senayanpost.com

\subsection{Ethanol}

Ethanol is usually derived from biomass/plants that contain sugar, starch or cellulose material, and not from natural gas. Ethanol is produced through the fermentation process using yeast. Ethanol can be used for SI and CI engines with several modifications. Currently, the price of ethanol reaches 5 times that of gasoline, so it is not feasible to be used as an alternative non-mixed fuel. Utilization of various food crops as ethanol raw material will cause socioeconomic problems for large scale production.

As an alternative fuel, ethanol has the advantage of being renewable and having a higher octane value than gasoline (107 RON). It is possible to apply ethanol on engines with high compression ratios (up to 19.5) to increase thermal efficiency and exhaust emissions. Meanwhile, for ethanol applications with high concentrations, modifications are needed not only in the compression ratio but also in some engine components so that the vehicle can run smoothly and prevent damage. In one study, with a complex engine control system and an optimized exhaust recirculation system, cars running on the E50 were able to produce fuel efficiency equivalent to gasoline cars [32]. 
However, ethanol contains dissolved and insoluble elements [33]. The soluble element is a chloride ion which has corrosive properties. These ions will attack the anti-rust coating on metals so that it will corrode and increase the conductivity of the fuel. Soluble elements, such as aluminum hydroxide, will clog up the fuel system. Ethanol is hygroscopic which absorbs water vapor directly from the atmosphere. The water content in ethanol will reduce combustion energy and cause knocking on the engine. To avoid this risk, ethanol must be sealed during storage. However, it will be difficult because in the fuel tank ventilation valves must be provided to prevent vacuum.

Corrosion will damage metals, including fuel tanks, fuel system components made of plastic and rubber, injectors, and deposits [34]. In 2001, several vehicle models using alcohol fuel in Japan were reported to have leaked fuel and caught fire due to corrosion on aluminum fuel system components. Then, the investigation is carried out by the team. To prove this, immersion tests are carried out on metals and other materials used in the fuel system to determine corrosion resistance to ethanol contained in fuels. The results of this study indicate that high ethanol concentrations cause corrosion in fuel system components made of aluminum [35].

In Indonesia, despite having abundant biological resources for ethanol [36], [37], the practice of using ethanol for commercial vehicles is currently not done. Provision of facilities and ethanol prices are much higher than gasoline, making this clean fuel not feasible to be implemented at this time. However, policy packages and advances in production technology such as in Brazil can be adopted in the future [38]-[40].

\subsection{Biodiesel}

Biodiesel can be produced from various plants which contain oil, soybean, sunflower, and coconut. In a term commonly known as RME (Rapeseed Methyl Ester). Esterification is an inexpensive way to convert vegetable oil molecules into molecules similar to diesel oil hydrocarbons, even though the cost of biodiesel is still higher than diesel oil. With properties very similar to diesel fuel, biodiesel can be directly used on existing diesel vehicles and mixed with fossil diesel in any ratio. Biodiesel has a lower energy content than diesel oil (about $8 \%$ ), but has a higher density and results in better ignition quality with a higher cetane number.

Biodiesel is a renewable biodegradable fuel that can also be produced from vegetable oils, animal fats, or recycled restaurant fats. Biodiesel is a substitute for burning cleaner diesel fuel. Biodiesel meets key properties as a CI engine fuel as a whole from the Renewable Fuel Standard. The performance of biodiesel in cold weather depends on the size of the mixture of biodiesel and raw materials to make it. In general, the smaller the percentage of biodiesel in the mixture, the better its performance at cold temperatures [41].
The national palm oil-based biodiesel industry growth significantly in 2018. Two drivers of this massive production exist, B20's national expansion into the non-public transport sector and huge international demand. Domestic demand is expected to increase significantly in the transport and manufacturing sectors in the coming years. In the meantime, exports are expected to remain strong on the basis of continued EU and Chinese demand [42]. Several studies report on the possible production of biodiesel in Indonesia and several researchers believe that biodiesel can be used as a single fuel or as mixed fuel in transport and industry, such as fishing boat fuel and agricultural machinery [43]-[48]. There is also much fundamental work for the enhancement of property and the assessment of its use in the automotive sector [49]-[53]. This is not only the case with palm biodiesel, but also biodiesel from the biodiversity of Indonesia [54]-[60]. Examples of commercialization and promotion of biodiesel are presented in Figure 3.

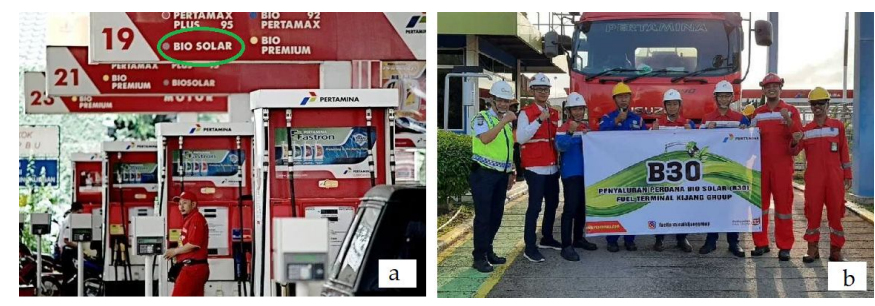

Figure 3: The implementation of biodiesel in Indonesia: (a) B20 available at almost all refueling sites, captured by radartasikmalaya.com; and (b) Promotion of B30 by Pertamina, captured by otomotif.kompas.com

\section{CONCLUSION}

LPG, CNG, ethanol and biodiesel are good candidates to replace conventional fuels for land transportation in Indonesia. Nevertheless, they have unique characteristics. LPG is relatively easy to implement because it only requires minor modifications to the engine. With the right conversion, savings and environmental effects can be received. In fact, new cars available in the Indonesian market have been adapted for LPG applications. However, LPG is a refinery product, its production capacity depends on the availability of crude oil. In the short term, maybe 10 years into the future, LPG is still promising even though this is not a good fuel for the future.

CNG provides advantages over LPG. The lower carbon content and high octane number provide better environmental effects and can be applied to machines with a higher compression ratio. In addition to SI engines, CNG is more reliable to be applied to diesel engines. Indonesia has abundant natural gas reserves to produce $\mathrm{CNG}$ at more competitive prices than LPG, gasoline, and diesel. This availability factor makes CNG more promising for current and future fuels. However, although both are gas-based, the implementation of $\mathrm{CNG}$ requires greater investment than $\mathrm{CNG}$, from the provision of infrastructure and conversion costs. 
Affan Rifa'i et al., International Journal of Emerging Trends in Engineering Research, 8(7), July 2020, 3784- 3790

Ethanol has almost all the key characteristics for a cleaner SI engine fuel. Although the energy content is lower than gasoline, technological advances can be applied to improve it. Ethanol is suitable for vehicles designed specifically for this purpose, but requires major modifications to existing vehicles. Indonesia has abundant biodiversity to produce ethanol. However, large-scale production will conflict with the availability of land for food crop production.

Biodiesel has been produced on a large scale in Indonesia. Palm, Jatropha curcas, sunflowers and all seeds containing oil can be planted throughout the islands in Indonesia. One of the features of biodiesel is that it can be applied independently or mixed with diesel oil. With quality improvements, biodiesel can be applied to diesel engines without engine modification. Large-scale implementation of biodiesel for heavy-duty vehicles can reduce oil imports. With adequate policy support, biodiesel production can be significantly increased by utilizing Indonesia's biodiversity and domestic workforce from upstream to downstream.

\section{ACKNOWLEDGEMENT}

The authors would like to thank the Center for Energy Studies - Universitas Muhammadiyah Magelang for data and references.

\section{REFERENCES}

[1] APEC, "Energy Demand and Supply Outlook 2016." .

[2] Ministry of Energy and Mineral Resources, "Handbook of Energy \& Economic Statistics of Indonesia 2012." Jakarta, 2013.

[3] M. H. Rahmat, "RUEN, Rencana Umum Energi Nasional." Seketariat Kabinet Republik Indonesia, diakses dalam http://setkab. go. id ..., 2017.

[4] D. Lavee and N. Becker, "Cost-benefit analysis of an accelerated vehicle-retirement programme," Journal of Environmental Planning and Management, vol. 52, no. 6, pp. 777-795, 2009. https://doi.org/10.1080/09640560903083731

[5] U. Lachapelle, "Using an accelerated vehicle retirement program (AVRP) to support a mode shift: Car purchase and modal intentions following program participation," Journal of Transport and Land Use, vol. 8, no. 2, pp. 107-123, 2015.

[6] Deendarlianto et al., "Scenarios analysis of energy mix for road transportation sector in Indonesia," Renewable and Sustainable Energy Reviews, vol. 70, no. November, pp. 13-23, 2017.

[7] ICCT, "Opportunities to Reduce Vehicle Emissions in Jakarta," 2014.

[8] A. Pratama and A. Tokai, "Passenger Vehicle Emissions in Indonesia: Future Projections," Journal of Sustainable Development, vol. 11, no. 6, p. 222, 2018. https://doi.org/10.5539/jsd.v11n6p222

[9] T. Kivevele, T. Raja, V. Pirouzfar, B. Waluyo, and M.
Setiyo, "LPG-Fueled Vehicles: An Overview of Technology and Market Trend," Automotive Experiences, vol. 3, no. 1, pp. 6-19, 2020. https://doi.org/10.31603/ae.v3i1.3334

[10] Institut Francais du Petrole, "EETP: European Emission Test Programme," Rueil-Malmaison, 2004.

[11] M. Setiyo and Suyitno, Teknologi Kendaraan Berbahan Bakar LPG. Yogyakarta: Deepublish, 2019.

[12] V. Susanti, A. Hartanto, A. S. Ridwan, M. S. Hendri, R. Estiko, and A. Hapid, "Fuel Subsidy and Air Pollution Reduction by Policy Program Of Conversion Fuel CNG for Vehicles in West Java Province," Journal of Mechatronics, Electrical Power, and Vehicular Technology, vol. 1, no. 2, pp. 43-52, 2010.

[13] M. Setiyo, S. Soeparman, N. Hamidi, and S. Wahyudi, "Techno-economic analysis of liquid petroleum gas fueled vehicles as public transportation in Indonesia," International Journal of Energy Economics and Policy, vol. 6, no. 3, pp. 495-500, 2016.

[14] M. Mahendra, Y. Muharam, S. Kartohardjono, and F. Giffari, "Modeling Of LGV Supply Chain System for Land Transportation Sector," Procedia Chemistry, vol. 9, pp. 284-294, 2014.

[15] B. Yunianto, "pengaruh perubahan saat penyalaan (ignition timing) terhadap prestasi mesin pada sepeda motor 4 langkah dengan bahan bakar lpg," Rotasi, vol. 11, no. 3, pp. 1-4, 2009.

[16] N. Supriyana and T. Hidayat, "Uji Performa Pengaruh Ignition Timing Terhadap Kinerja Motor Bensin Berbahan Bakar LPG," Simetris: Jurnal Teknik Mesin, Elektro dan Ilmu Komputer, vol. 6, no. 2, pp. 231-236, 2015.

[17] N. Romandoni, "Studi Komparasi Performa Mesin Dan Kadar Emisi Gas Buang Sepeda Motor Empat Langkah Berbahan Bakar Bensin Dan Lpg," Jurnal Teknik Mesin, vol. 1, no. 2, pp. 1-9, 2012.

[18] I. Kurniaty and H. Hermansyah, "Potensi Pemanfaatan LPG (Liquefied Petroleum Gas) Sebagai Bahan Bakar Bagi Pengguna Kendaraan Bermotor," Prosiding Semnastek, 2016.

[19] S. A. R. Alvando Lengkong and D. H. Sutjahjo, "Pengaruh Penggunaan Bahan Bakar LPG Terhadap Efisiensi Thermal, Ekonomisasi, Dan Konsumsi Bahan Bakar Mobil Toyota Kijang 5k," Jurnal Teknik Mesin, vol. 1, no. 3, pp. 101-105, 2013.

[20] B. C. Purnomo and N. Widodo, "Torque and Power Characteristics of Single Piston LPG-Fueled Engines on Variations of Ignition Timing," Automotive Experiences, vol. 2, no. 1, pp. 22-27, 2019.

[21] M. I. Rosyidi, E. M. Widodo, T. A. Purnomo, M. Setiyo, and D. W. Karmiadji, "Converting ToD Vehicle from Gasoline to LPG in Indonesia: Cost Identification and Investment Analysis," International Journal of Technology, vol. 11, no. 1, pp. 100-110, 2020. https://doi.org/10.14716/ijtech.v11i1.2161

[22] E. M. Widodo et al., "Environmental benefit of public fleet fueled by LPG / Vi-Gas in Magelang City , 
Affan Rifa'i et al., International Journal of Emerging Trends in Engineering Research, 8(7), July 2020, 3784- 3790

Indonesia : A Simulation Study," in IOP Conference Series: Materials Science and Engineering, 2019, pp. $1-6$.

[23] M. Setiyo, E. M. Widodo, M. I. Rosyidi, B. Waluyo, Z. B. Pambuko, and N. Tamaldin, "Feasibility study on small cars as an alternative to conventional fleets due to low occupancy: case study in Indonesia," Heliyon, vol. 6, no. 1, p. e03318, 2020.

[24] M. Setiyo, E. M. Widodo, M. I. Rosyidi, T. A. Purnomo, B. S. Rahardja, and S. Suryantoro, "Economic values and $\mathrm{CO} 2$ simulation on the application of LPG for public fleets in magelang, Indonesia: Executive data to support the clean city program," Periodica Polytechnica Transportation Engineering, vol. 48, no. 2, pp. 159-172, 2020.

[25] E. M. Widodo, M. I. Rosyidi, T. A. Purnomo, and M. Setiyo, "Converting Vehicle to LPG/Vigas: A Simple Calculator to Assess Project Feasibility," Automotive Experiences, vol. 2, no. 2, pp. 34-40, 2019.

[26] H. Syukur, "Potensi Gas Alam Di Indonesia," Swara Patra, vol. 6, no. 1, 2016.

[27] H. Allen, K. Millard, M. S. U. Rahman, and T. Barlow, "A Study on Potential Use of Compressed Natural Gas (CNG) in Public Transport in Indonesia," Crowthorne, 2015.

[28] S. B. Nugroho, E. Zusman, R. Nakano, and J. Fujino, "Enabling purposive experimentation in the transport sector: The case of BRT improvement and CNG conversion in Semarang, Indonesia," in Sustainability and the Automobile Industry in Asia, Routledge, 2020, pp. 61-73.

[29] I. Kurniaty, "Evaluasi Aspek Finansial Penghematan Bahan Bakar Bensin Menjadi CNG (Compressed Natural Gas) Untuk Mobil Pribadi," JURNAL KONVERSI, vol. 6, no. 1, pp. 43-50, 2017.

[30] Y. Putrasari, A. Praptijanto, A. Nur, B. Wahono, and W. B. Santoso, "Evaluation of performance and emission of SI engine fuelled with CNG at low and high load condition," Energy procedia, vol. 68, pp. 147-156, 2015.

https://doi.org/10.1016/j.egypro.2015.03.243

[31] Roni Muhammad Susanto and M. Setiyo, "Natural Gas Vehicle (NGV): Status Teknologi dan Peluang Status Teknologi dan Peluang Pengembangannya," Automotive Experiences, vol. 1, no. 1, pp. 1-6, 2018.

[32] M. Bakenhus, "Economical , High-Efficiency Engine Technologies for Alcohol Fuels," American Energy Independence, 2016.

[33] N. D. Brinkman, R. Halsall, Scott W. Jorgensen, and J. E. Kirwan, "The Development of Improved Fuel Specifications for Methanol (M85) and Ethanol (Ed85)," SAE Technical Paper, vol. 1994-3-1, 1994.

[34] M. Setiyo, Saifudin, A. W. Jamin, R. Nugroho, and D. W. Karmiadji, "The Effect of Ethanol on Fuel Tank Corrosion Rate," Jurnal Teknologi, vol. 80, no. 6, pp. $19-25,2018$.

[35] A. Kameoka, K. Nagai, G. Sugiyama, and T. Seko,
"Effect of Alcohol Fuels on Fuel-Line Materials of Gasoline Vehicles," Powertrain \& Fluid Systems Conference \& Exhibition Technical Papers, no. 2005-01-3708. 2005.

[36] Y. Putrasari, A. Praptijanto, W. B. Santoso, and O. Lim, "Resources, policy, and research activities of biofuel in Indonesia: A review," Energy Reports, vol. 2, pp. 237-245, 2016.

[37] D. Khatiwada and S. Silveira, "Scenarios for bioethanol production in Indonesia: How can we meet mandatory blending targets?," Energy, vol. 119, pp. 351-361, 2017. https://doi.org/10.1016/j.energy.2016.12.073

[38] J. Goldemberg, "Sugarcane ethanol: strategies to a successful program in Brazil," in Advanced biofuels and bioproducts, Springer, 2013, pp. 13-20.

[39] P. Grad, "Biofuelling Brazil: An overview of the bioethanol success story in Brazil," Refocus, vol. 7, no. 3, pp. 56-59, 2006.

[40] A. K. Chandel et al., "Techno-economic analysis of second-generation ethanol in Brazil: competitive, complementary aspects with first-generation ethanol," in Biofuels in Brazil, Springer, 2014, pp. 1-29.

[41] US Department of Energy, "Biodiesel Fuel Basics," Alternative Fuels Data Center, 2012. [Online]. Available:

http://www.afdc.energy.gov/fuels/biodiesel_basics.html . [Accessed: 05-Mar-2018].

[42] A. Rahmanulloh, "Indonesia Biofuels Annual Report 2019," Jakarta, 2019.

[43] F. Harahap, S. Silveira, and D. Khatiwada, "Cost competitiveness of palm oil biodiesel production in Indonesia," Energy, vol. 170, pp. 62-72, 2019.

[44] K. Siregar, A. H. Tambunan, A. K. Irwanto, S. S. Wirawan, and T. Araki, "A Comparison of Life Cycle Assessment on Oil Palm (Elaeis guineensis Jacq.) and Physic Nut (Jatropha curcas Linn.) as Feedstock for Biodiesel Production in Indonesia," Energy Procedia, vol. 65, pp. 170-179, 2015.

[45] H. Kamahara et al., "Improvement potential for net energy balance of biodiesel derived from palm oil: A case study from Indonesian practice," Biomass and Bioenergy, vol. 34, no. 12, pp. 1818-1824, 2010.

[46] A. S. Silitonga, A. E. Atabani, T. M. I. Mahlia, H. H. Masjuki, I. A. Badruddin, and S. Mekhilef, "A review on prospect of Jatropha curcas for biodiesel in Indonesia," Renewable and Sustainable Energy Reviews, vol. 15, no. 8, pp. 3733-3756, 2011.

[47] M. H. Jayed, H. H. Masjuki, M. A. Kalam, T. M. I. Mahlia, M. Husnawan, and A. M. Liaquat, "Prospects of dedicated biodiesel engine vehicles in Malaysia and Indonesia," Renewable and Sustainable Energy Reviews, vol. 15, no. 1, pp. 220-235, 2011. https://doi.org/10.1016/j.rser.2010.09.002

[48] N. Indrawan et al., "Palm biodiesel prospect in the Indonesian power sector," Environmental Technology \& Innovation, vol. 7, pp. 110-127, 2017. 
[49] E. Marlina, M. Basjir, M. Ichiyanagi, T. Suzuki, G. J. Gotama, and W. Anggono, "The Role of Eucalyptus Oil in Crude Palm Oil As Biodiesel Fuel," Automotive Experiences, vol. 3, no. 1, pp. 33-38, 2020.

[50] D. Ayu, R. Aulyana, E. W. Astuti, K. Kusmiyati, and N. Hidayati, "Catalytic Transesterification of Used Cooking Oil to Biodiesel: Effect of Oil-Methanol Molar Ratio and Reaction Time," Automotive Experiences, vol. 2, no. 3, pp. 73-77, 2019.

[51] H. Y. Nanlohy, H. Riupassa, I. M. Rasta, and M. Yamaguchi, "An Experimental Study on the Ignition Behavior of Blended Fuels Droplets with Crude Coconut Oil and Liquid Metal Catalyst," Automotive Experiences, vol. 3, no. 2, 2020.

[52] H. Y. Nanlohy, I. N. G. Wardana, M. Yamaguchi, and T. Ueda, "The role of rhodium sulfate on the bond angles of triglyceride molecules and their effect on the combustion characteristics of crude jatropha oil droplets," Fuel, vol. 279, p. 118373, 2020.

[53] A. C. Arifin, A. Aminudin, and R. M. Putra, "Diesel-Biodiesel Blend on Engine Performance: An Experimental Study," Automotive Experiences, vol. 2, no. 3, pp. 91-96, 2019.

[54] M. L. Sanyang, S. M. Sapuan, M. Jawaid, M. R. Ishak, and J. Sahari, "Recent developments in sugar palm (Arenga pinnata) based biocomposites and their potential industrial applications: A review," Renewable and Sustainable Energy Reviews, vol. 54, pp. 533-549, 2016.

[55] P. A. Handayani, A. Abdullah, and H. Hadiyanto, "Biodiesel production from Nyamplung (Calophyllum inophyllum) oil using ionic liquid as a catalyst and microwave heating system," Bulletin of Chemical Reaction Engineering \& Catalysis, vol. 12, no. 2, pp. 293-298, 2017.

[56] M. Fadhlullah, S. N. B. Widiyanto, and E. Restiawaty, "The potential of nyamplung (Calophyllum inophyllum L.) seed oil as biodiesel feedstock: Effect of seed moisture content and particle size on oil yield," Energy Procedia, vol. 68, no. 2015, pp. 177-185, 2015. https://doi.org/10.1016/j.egypro.2015.03.246

[57] S. Supriyadi and P. Purwanto, "Enhancing biodiesel from kemiri sunan oil manufacturing using ultrasonics," in E3S Web of Conferences, 2018, vol. 31, p. 2014.

[58] W. S. Wulandari, D. Darusman, and W. Cecep Kusmana, "Land suitability analysis of biodiesel crop Kemiri Sunan (Reutealis trisperma (Blanco) Airy Shaw) in the Province of West Java, Indonesia," J Environ Earth Sci, vol. 4, no. 21, pp. 27-37, 2014.

[59] N. A. Fauzan, E. S. Tan, F. L. Pua, and G. Muthaiyah, "Physiochemical properties evaluation of Calophyllum inophyllum biodiesel for gas turbine application," South African Journal of Chemical Engineering, vol. 32, pp. 56-61, 2020.

[60] A. S. Silitonga, H. H. Masjuki, H. C. Ong, T. Yusaf, F. Kusumo, and T. M. I. Mahlia, "Synthesis and optimization of Hevea brasiliensis and Ricinus communis as feedstock for biodiesel production: A comparative study," Industrial Crops and Products, vol. 85, pp. 274-286, 2016.

https://doi.org/10.1016/j.indcrop.2016.03.017 